\title{
Editorial: A first collaborative attempt at a global revision of Trypetheliaceae (Ascomycota: Dothideomycetes: Trypetheliales)
}

In the past two decades, the taxonomy and systematics of tropical lichens have received increased attention. Tropical lichen biotas are dominated by crustose microlichens, particularly Arthoniaceae, Caliciaceae, Graphidaceae, Lecanoraceae, Malmideaceae, Opegraphaceae, Pertusariaceae, Porinaceae, Pyrenulaceae, Ramalinaceae, Roccellaceae, and Trypetheliaceae (Cáceres 2007; Rivas Plata et al. 2008; Lücking et al. 2009). Whereas Graphidaceae, by far the largest family, are by now relatively well-known (Staiger 2002; Frisch et al. 2006; Rivas Plata et al. 2012) and identification tools exist for families such as Malmideaceae and Pyrenulaceae (Aptroot 2012; Breuss \& Lücking 2015), most have no comprehensive treatments available.
Here, we present a first attempt at a global revision of Trypetheliaceae, the second most important component in tropical regions after Graphidaceae. In analogy to the latter, generic concepts in Trypetheliaceae were long based on ascoma organisation and ascospore septation, resulting in artificial entities. Molecular phylogenetic studies contributed to a more natural generic concept, with surprising results and dramatic changes. While the number of genera now recognized remained almost unchanged, the inclusion of species previously classified in Arthopyrenia and Mycomicrothelia in the family and the fusion of Astrothelium, Campylothelium, Cryptothelium, and the bulk of species previously classified in Trypethelium, into what is now recognized as a single, megadiverse
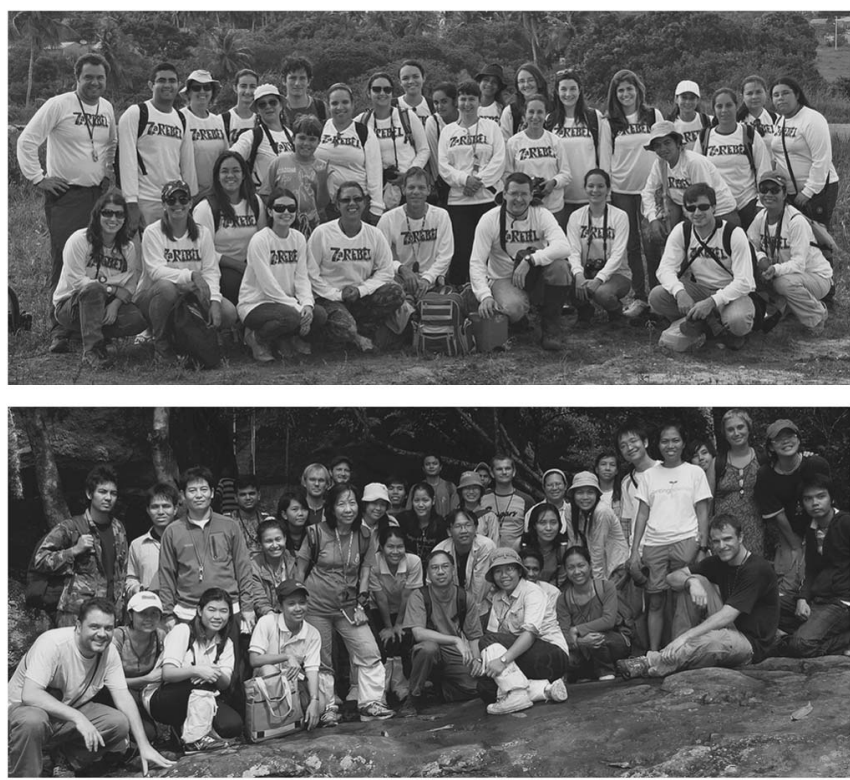

FIG. 1. REBEL meeting 2013 in northeastern Brazil (above). Many new taxa in Trypetheliaceae have been found in this area and in the Amazon and students shown here have participated in their discovery and publication. Thelotremataceae workshop 2008 in Thailand (below). Several of the students depicted there are now active, successful lichenologists and some have contributed to this work on Trypetheliaceae. 
genus Astrothelium, is in stark contrast with the previous classification and delimitation of Trypetheliaceae.

Globalization has long entered the scientific world and the combination of different expertise with broad geographic coverage makes it possible to cover a taxon from every possible angle, bringing together traditional taxonomy, type studies, and nomenclature, with molecular phylogenetics and other quantitative tools. The core of this work is based on long ongoing taxonomic revisions of pyrenocarpous groups by the first author, a comprehensive molecular phylogeny enthusiatically assembled by M.P. Nelsen as part of his PhD thesis work at the University of Chicago and The Field Museum, and ongoing inventories of tropical crustose microlichens spearheaded by both authors and H.J.M. Sipman, who placed numerous specimens at our disposal. Access to biodiversity in tropical areas, facilitated through international collaborations, has been crucial and also resulted in the training of local students and professionals (Fig. 1). Another important component is the ongoing digitization of herbarium specimens, in particular types, through projects such the Global Plants Initiative [http://gpi.myspecies.info; https:// plants.jstor.org], which made it possible to track down even some of the most obscure names and elucidate their status. Last but not least, the outstanding editorial team of The Lichenologist helped to assemble this collaborative treatment into a special issue.

As a result, this issue contains nine contributions from 46 authors representing 26 countries. In the first six papers (pp. 609-737), 136 new species of Trypetheliaceae are described from different tropical areas, focusing on the Neotropics and the eastern Palaeotropics. Many are based on phylogenetic studies, and the work by Luangsuphabool et al. (pp. 727-737) is a nice example of where detailed analysis in a small target group can reveal unexpected diversity. Lücking et al. (pp. 739-762) provide a much expanded phylogenetic framework for the family, based on the earlier study by Nelsen et al. (2014), but with a focus on species-level clades. The family is revised synoptically by
Aptroot \& Lücking (pp. 763-982), with keys to genera and species, extensive synonymy, and brief descriptions for all taxa are crossreferenced to those introduced in the other papers. Finally, Aptroot et al. (pp. 983-994) predict that, with over 400 species now recognized, compared to approximately 200 in the latest Dictionary of the Fungi (Kirk et al. 2008), the family might contain up to 800 species. Much work remains to be done!

\section{REFERENCES}

Aptroot, A. (2012) A world key to the species of Anthracothecium and Pyrenula. Lichenologist 44: 5-53.

Breuss, O. \& Lücking, R. (2015) Three new lichen species from Nicaragua, with keys to the known species of Eugeniella and Malmidea. Lichenologist 47: 9-20.

Cáceres, M. E. S. (2007) Corticolous crustose and microfoliose lichens of northeastern Brazil. Libri Botanici 22: 1-168.

Frisch, A., Kalb, K. \& Grube, M. (2006) Contributions towards a new systematics of the lichen family Thelotremataceae. Bibliotheca Lichenologica 92: 1-556.

Kirk, P. M., Cannon, P. F., Minter, D. W. \& Stalpers, J. A. (2008) Dictionary of the Fungi (10th Edn.). CAB International, Wallingford, UK.

Lücking, R., Rivas-Plata, E., Chavez, J. L., Umaña, L. \& Sipman, H. J. M. (2009) How many tropical lichens are there ... really? Bibliotheca Lichenologica 100: 399-418.

Nelsen, M. P., Lücking, R., Aptroot, A., Andrew, C. J., Cáceres, M. E. S., Rivas Plata, E., Gueidan, C., Canêz, L. S., Knight, A., Ludwig, L. R., et al. (2014) Elucidating phylogenetic relationships and genus-level classification within the fungal family Trypetheliaceae (Dothideomycetes: Ascomycota). Taxon 63: 974-992.

Rivas Plata, E., Lücking, R. \& Lumbsch, H. T. (2008) When family matters: an analysis of Thelotremataceae (lichenized Ascomycota: Ostropales) as bioindicators of ecological continuity in tropical forests. Biodiversity and Conservation 17: 1319-1351.

Rivas Plata, E., Lücking, R. \& Lumbsch, H. T. (2012) A new classification for the family Graphidaceae (Ascomycota: Lecanoromycetes: Ostropales). Fungal Diversity 52: 107-121.

Staiger, B. (2002) Die Flechtenfamilie Graphidaceae. Studien in Richtung einer natürlicheren Gliederung. Bibliotheca Lichenologica 85: 1-526.

\section{André Aptroot and Robert Lücking}

A. Aptroot: ABL Herbarium, G.v.d.Veenstraat 107, NL-3762 XK Soest, The Netherlands.

R. Lücking: Botanical Garden and Botanical Museum Berlin, Königin-Luise-Straße 6-8, 14195 Berlin, Germany; Research Associate, Integrative Research Center, The Field Museum, 1400 South Lake Shore, Chicago, IL 60605, USA. 